\title{
The Elephant in the Handaxe: Lower Palaeolithic Ontologies and Representations
}

\author{
Ran Barkai
}

\begin{abstract}
Indigenous hunter-gatherers view the world differently than do WEIRD (Western, Educated, Industrialized, Rich and Democratic) societies. They depend-as in prehistoric times-on intimate relationships with elements such as animals, plants and stones for their successful adaptation and prosperity. The desire to maintain the perceived world-order and ensure the continued availability of whatever is necessary for human existence and well-being thus compelled equal efforts to please these otherthan-human counterparts. Relationships of consumption and appreciation characterized human nature as early as the Lower Palaeolithic; the archaeological record reflects such ontological and cosmological conceptions to some extent. Central to my argument are elephants and handaxes, the two pre-eminent Lower Palaeolithic hallmarks of the Old World. I argue that proboscideans had a dual dietary and cosmological significance for early humans during Lower Paleolithic times. The persistent production and use of the ultimate megaherbivore processing tool, the handaxe, coupled with the conspicuous presence of handaxes made of elephant bones, serve as silent testimony for the elephant-handaxe ontological nexus. I will suggest that material culture is a product of people's relationships with the world. Early humans thus tailored their tool kits to the consumption and appreciation of specific animal taxa: in our case, the elephant in the handaxe.
\end{abstract}

\begin{abstract}
When we look about us on the earth, what we see is colored by our worldview and the languages that we use to describe our observations. A landscape of streams and lakes, mountains and rich valleys, shared by thousands of species of plants and animals, is understood through the lens of the western materialist worldview as a wealth of ecosystem services or natural resources. In contrast, through the lens of traditional Indigenous philosophy the living world is understood, not as a collection of exploitable resources, but as a set of relationships and responsibilities.
\end{abstract}

Kimmerer $(2018,27)$

\section{Introduction}

Today a thriving human lineage occupies every continent, whereas the elephant lineage, comprising some of the largest mammals that ever walked on Earth, is endangered and geographically restricted to regions of Africa and Asia. ('Elephant' refers to all members of the Proboscidea taxonomic order, extant and extinct). Seven million years ago, the human clade underwent its earliest evolutionary divergence in Africa, while megaherbivores, including several proboscidean taxa, were distributed across the globe and showed impressive taxonomic diversity and richness (Faith et al. 2018). Therefore, human evolutionary history is characterized by the co-existence of humans and proboscideans, and the prehistoric archaeological record testifies to humanelephant interactions throughout time and space. In parts of Asia and Africa, close to the equator, the human-elephant interaction continues today, following a legacy of hundreds of thousands of years. In

Cambridge Archaeological Journal 31:2, 349-361 @ The Author(s), 2021. Published by Cambridge University Press on behalf of the McDonald Institute for Archaeological Research. This is an Open Access article, distributed under the terms of the Creative Commons Attribution licence (http:// creativecommons.org/licenses/by/4.0/), which permits unrestricted re-use, distribution, and reproduction in any medium, provided the original work is properly cited. 
Europe, the rest of Asia and America, however, this interaction ended at the terminal Pleistocene, with the extinction of proboscideans. In specific regions in Africa and the Levant, however, the disappearance of elephants seems to have occurred during the Middle Pleistocene and was linked to significant cultural and technological transformations in human behaviour and adaptation strategies (Barkai et al. 2017; Ben-Dor et al. 2011; Blasco et al. 2019a,b; Potts et al. 2018). Prehistoric sites throughout the Old and New Worlds present ubiquitous evidence for the significant role in diet and culture elephants played in early human adaptation and well-being during the Palaeolithic (c. 2 million-10,000 years ago). Proboscidean remains are found in many Pleistocene sites and are associated with several human species (e.g. Homo erectus, H. neanderthalensis and $H$. sapiens).

Palaeolithic nutrition was based on animal meat and fat, in addition to vegetal sources, and archaeological sites bear evidence of elephant exploitation for dietary purposes by the use of stone tools. I argue that Proboscideans, when available, provided an unprecedented food-package for early humans, and that actually successful human subsistence depended largely on megaherbivores. Moreover, the central role of elephants as a food source, coupled with the social and behavioural similarities between elephants and humans (Lev \& Barkai 2016), might explain the inclusion of these animals in early human cosmology and symbolic expressions (most vividly expressed in Palaeolithic parietal and mobile imagery: see e.g. Braun \& Palombo 2012; Hussain \& Floss 2015).

Homo erectus, the ancestor of Homo sapiens and Neanderthals, was obliged by their increased body size and energetically expensive brain and by the ceiling on the amount of protein they could safely digest to consume large animals high in fat. An association between the large-brained Homo erectus and the increased consumption of meat and fat, associated also with primary access to carcases, has been noted (e.g. Aiello \& Wheeler 1995; Pobiner et al. 2008), with some researchers concluding that Homo erectus evolved to be a member of the hypercarnivore guild (e.g. Domínguez-Rodrigo \& Pickering 2017; Werdelin \& Lewis 2013). I highlight the significance of proboscideans in human diet, culture and wellbeing in the Lower Palaeolithic, as well as the persistent production and use of the iconic Acheulean handaxes. I argue towards a dual functional-ontological link between elephants and handaxes and suggest that the extraordinary pattern of using broken elephant bones for the production of bone handaxes is a manifestation of Lower Palaeolithic cosmologies and ontologies, centred on the elephant.

\section{Fat, meat and the role of elephants in indigenous hunter-gatherer societies}

Most indigenous hunter-gatherer societies depend to a significant extent-as they did in prehistoric times-on calories extracted from land and sea mammals. This was true mostly during Lower and Middle Palaeolithic times, when megaherbivores roamed the landscape presenting the highest biomass density (Ben-Dor \& Barkai 2020) and continued ever since, although the extent of plant consumption by humans rose since the late Quaternary extinction of megafauna some 40,000 years ago. Fat and meat fuelled human biological and cultural evolution, and the well-documented indigenous craving for fat and meat in recent societies (e.g. Biesele 1993; Tanner 2014) is also reflected at prehistoric sites throughout the Old and New Worlds by the ubiquitous presence of the remains of consumed prey and the emphasis on fat acquisition (e.g. Ben-Dor et al. 2011; 2016; Blasco et al. 2019b; Boschian et al. 2019; Morin 2020; Solodenko et al. 2015; Speth 2020).

Fat and protein have been recognized as essential elements in human diet during the Pleistocene (e.g. Bunn 2006; Domínguez-Rodrigo \& Pickering 2017), in addition to complementary calories from vegetal sources (Hardy et al. 2015). Fat and protein from animal carcasses are a source of essential amino acids, minerals, vitamins and fatty acids (Friedman 1996; Givens et al. 2006). Fat provides 9 calories/gramme at a minimal digestion cost, while carbohydrates and protein provide only 4 calories/ gramme, and hence fat is the densest form of energy available in nature (Outram 2002). Its taste, too, has been documented to be favoured by humans (Reshef \& Barkai 2015), and it is plentiful in large herbivores even when other resources are scarce. Human protein consumption is also known to have accepted ceilings, dependent on the ability of the liver and renal system to dispose of its by-products (Ben-Dor et al. 2011; 2016). Thus, on average, humans are able to gain only about one-third of their daily calorific intake from meat (Speth 2020). Vegetal food is not always available and accessible, its processing is demanding and its digestion is energetically costly (Ben-Dor \& Barkai 2020). Prior to the habitual use of fire, plant consumption for dietary proposes must have been minimal (Barkai et al. 2017). Fat is available year-round, there are no physiological limitations on its consumption and it provides ultra-nutritious and tasty calorific supply. 
Homo erectus (senso lato) appeared on the scene some two million years ago in Africa, equipped with extended brain capacity, large body size and digestive and dental systems adapted towards high-energetic foods capable of sustaining the large brain and body (e.g. Aiello \& Wheeler 1995; Domínguez-Rodrigo \& Pickering 2017; Zink \& Lieberman 2016). Animal fat and marrow provided the necessary food intake for the essential daily energy expenditure, especially in cases where plants were not available in abundance and prior to the habitual use of fire for cooking (Ben-Dor et al. 2011). The Lower Palaeolithic archaeological record is indeed consistent with such a scenario (Barkai et al. 2017; Domínguez-Rodrigo \& Pickering 2017). This dependency on meat and fat led to the regular acquisition of animal carcasses by hunting (as well as scavenging) and a preference for megaherbivores such as elephants, mostly because they provided large quantities of high-quality fat (Agam \& Barkai 2016; 2018; Guil-Guerrero et al. 2018).

The hunting of very large animals, including elephants, was surely demanding, but does not require extraordinary means (Agam \& Barkai 2018; Churchill 1993; Lewis 2015). Moreover, the preferred human consumption of large animals can be deduced from the decline, and even disappearance, of large animal populations in Pleistocene Africa and the Levant (Ben-Dor \& Barkai 2020; Ben-Dor et al. 2011; Potts et al. 2018; Smith et al. 2018) and from the prominent role of elephants, along with other large mammals, at Early and Middle Pleistocene hominin sites worldwide.

Proboscideans, with their large size and high fat content, must have been an essential source of calories for early humans. In analysis of mammoths found in permafrost Siberia (Guil-Guerrero et al. 2018), fat-rich organs were suggested to be of ultimate importance for Stone Age hunters:

Brain, bone marrow, subcutaneous fat, viscera and meat would have been the targeted mammoth organs for Stone Age hunters and given the high energy needs of Stone Age hunters, protein-rich food, such as meat, should have been ingested to a lower extent than other fatty tissues. (Guil-Guerrero et al. 2018, 459)

Moreover, the authors suggested that the fat available from large mammals would have provided sustenance for a group of people for an extended period:

Achieving $4500 \mathrm{kcal}$, the previously estimated daily energy need at those times, would have been possible by consuming $\sim 566 \mathrm{~g}$ of meat complemented by $\sim 592$ $\mathrm{g}$ of fatty tissues, such as subcutaneous fat. For a mammoth of $\sim 3.0$ tons, $\sim 5 \%$ subcutaneous fat and other similar fats distributed throughout the body would be a conservative figure, and thus a medium-sized mammoth would have stored $\sim 1$ million kcal as fat, providing clean energy for a hunting group of 12-24 individuals for approximately 9-18 days, while the consumption of variable amounts of meat would have extended this figure for some days. (Guil-Guerrero et al. 2018, 461)

It should be stressed that the above calculations do not take into consideration the consumption of bone marrow, one of the most elementary nutrients and a favourable source of calories for Palaeolithic humans (Boschian et al. 2019). Thus, when the contribution by bone marrow is added to the sum of calories provided by a proboscidean, the quality and significance of this food package is surely unprecedented. Moreover, African Pleistocene elephants were much larger and heavier than the European mammoths (up to 8-10 tons in weight); their dietary potential is thus much higher than the above estimates. In addition, recent research on the fat composition of juvenile frozen mammoths shows a rare nutritional value of their fat itself, with a high concentration of polyunsaturated fatty acids, which are known to build up cell membranes. Fat from juveniles also had a higher nutritional profile due to milk intake (Guil-Guerrero et al. 2014). These nutritional properties, the large number of juvenile elephant bones found at various sites and the better taste of young animal fat might indicate a preference for proboscidean calves by Pleistocene humans (Reshef \& Barkai 2015). Moreover, it should be highlighted that isotopic studies indicated time and again that Palaeolithic humans consumed proboscidean meat and fat even in the absence of relevant bones in the faunal record, strongly indicating the underrepresentation of the role of megaherbivores in the Palaeolithic human diet (Bocherens 2009; 2011). Likewise, it was recently argued that both human behaviour in the past and the methods of calculating the contribution of large animals to the human diet in the present actually mask and underappreciate human dependency on calories provided by megaherbivores (Ben-Dor \& Barkai in press; Bocherens in press).

Palaeolithic sites demonstrate the ubiquitous consumption of large herbivores by early humans and it is becoming rather evident that hunting was practised as a primary procurement strategy for humans to meet their calorific and nutritional demands (Bunn 2019; Domínguez-Rodrigo \& Pickering 2017). There is also ample evidence that, during the Palaeolithic, elephant bones were used as material 
for tool production. Proboscidean bones were also used as fuel and as material for constructing dwelling structures and windbreaks. Furthermore, elephants and mammoths are also significantly represented in Palaeolithic parietal depictions and mobile 'art' in Upper Palaeolithic Europe and in the production of non-utilitarian items such as bone handaxes in Europe, Africa and Asia during Lower Palaeolithic times (Barkai 2019; Gaudzinski et al. 2005; Hussain \& Floss 2015; Zutovski \& Barkai 2016).

\section{Lower Palaeolithic stone handaxes, and the peculiar presence of handaxes made of elephant bone}

Stone tools provide a unique window into the mode of adaptation and cognitive abilities of Lower Palaeolithic early humans. As stone tools (along with animal bones) are often the sole remains of early human activities, the persistently produced large cutting tools (bifaces/handaxes) have long been an appealing focus of research in the reconstruction of Lower Palaeolithic survival strategies. In general, Lower Palaeolithic stone-tool technologies are characterized by flakes and flakes shaped as tools, while the canonic handaxe is considered as the most prominent Acheulian tool-type (see Finkel \& Barkai 2018). Handaxes (Fig. 1) are relatively large items shaped by bifacial flaking that reflects skilled production and in many cases extended life-history. Despite recent research that strongly highlights the variability and complexity of Acheulean lithic technologies, and most prominently the role of flakes in human adaptation (e.g. Agam et al. 2015; Lycett \& Gowlett 2008; Venditti et al. 2019a), the canonic handaxe still attracts most of the scholarly attention and is still considered as a hallmark of the Acheulian.

The available functional, technological, and experimental data imply that Lower Palaeolithic handaxes were most probably employed in animal carcass processing (e.g. P. Jones 1980; Keeley 1980, 160-70; Machin et al. 2007; Mitchell 1996; Solodenko et al. 2015). However, this issue is still hotly debated. Handaxes were sometimes in operation in the execution of tasks not related to animal carcass processing (e.g. Domínguez-Rodrigo et al. 2001; Hardy et al. 2018; Zupancich et al. 2018), and thus it was suggested that handaxes acted as multipurpose tools. I argue that the available data point towards repeated archaeological association of animal carcasses and handaxes (e.g. Goren-Inbar et al. 2018; Solodenko et al. 2015) as well as the efficient use of handaxes in de-fleshing and dismembering animal carcasses (Fig. 2), and in particular carcasses of large herbivores (e.g. P. Jones 1980; 1981; Key \& Lycett 2015; 2017).

A previous paper (Finkel \& Barkai 2018) addressed the dissonance between the alleged 'stasis' of the Acheulian handaxe for over one million years and the significant transformations in culture and biology throughout the Lower Palaeolithic period. Most research on this topic suffers from neophilia, the enthusiasm towards what is new and novel. We suggested instead that while persistency was preferred in handaxe manufacture and use, innovation took place at other realms of human behaviour and adaptation, enabled by the stability provided by the familiar mode of adaptation based on the assured performance of the good old handaxe. We highlighted the dependency of Acheulean hominins on megaherbivores for sustaining their energetic needs, and the significance of handaxes in supplying calories by efficiently processing large game. We argued that the pivotal role of the handaxe in Acheulean adaptation accorded it its fixed position in Acheulian technology and culture following human conformity and majority imitation. In short, we proposed that the persistence of the Acheulean handaxe acted as an adaptive mechanism based on preferred cultural conservatism, which allowed and enabled the successful adaptation of Lower Palaeolithic human groups in the Old World for over one million years.

It is true that Acheulean handaxes might have been used to process large animal carcasses other than elephants (for example horse processing at Boxgrove; see Pope \& Roberts 2005). In other cases, carcasses of large mammals such as elephants and horses seem to have been processed without handaxes (e.g. Aureli et al. 2015; Gallotti \& Peretto 2015; Van Kolfschoten et al. 2015). Thus, the alleged elephant-handaxe nexus is not obligatory for every encounter people had with elephants, but depends upon specific circumstances and interactions. Even if certain elephants, in certain situations, were conceived as other-than-human persons that must be treated, processed and consumed with respect, this need not always be the case. This point can be clarified by the case of Ojibwa ontology regarding how objects such as stones can, in certain circumstances, become animate:

Since stones are grammatically animate, I once asked an old man: Are all the stones we see about us here alive? He reflected a long while and then replied, 'No! But some are'... Whereas we should never expect a stone to manifest animate properties of any kind under any 
Figure 1. A handaxe from late Acheulean Revadim, Israel.

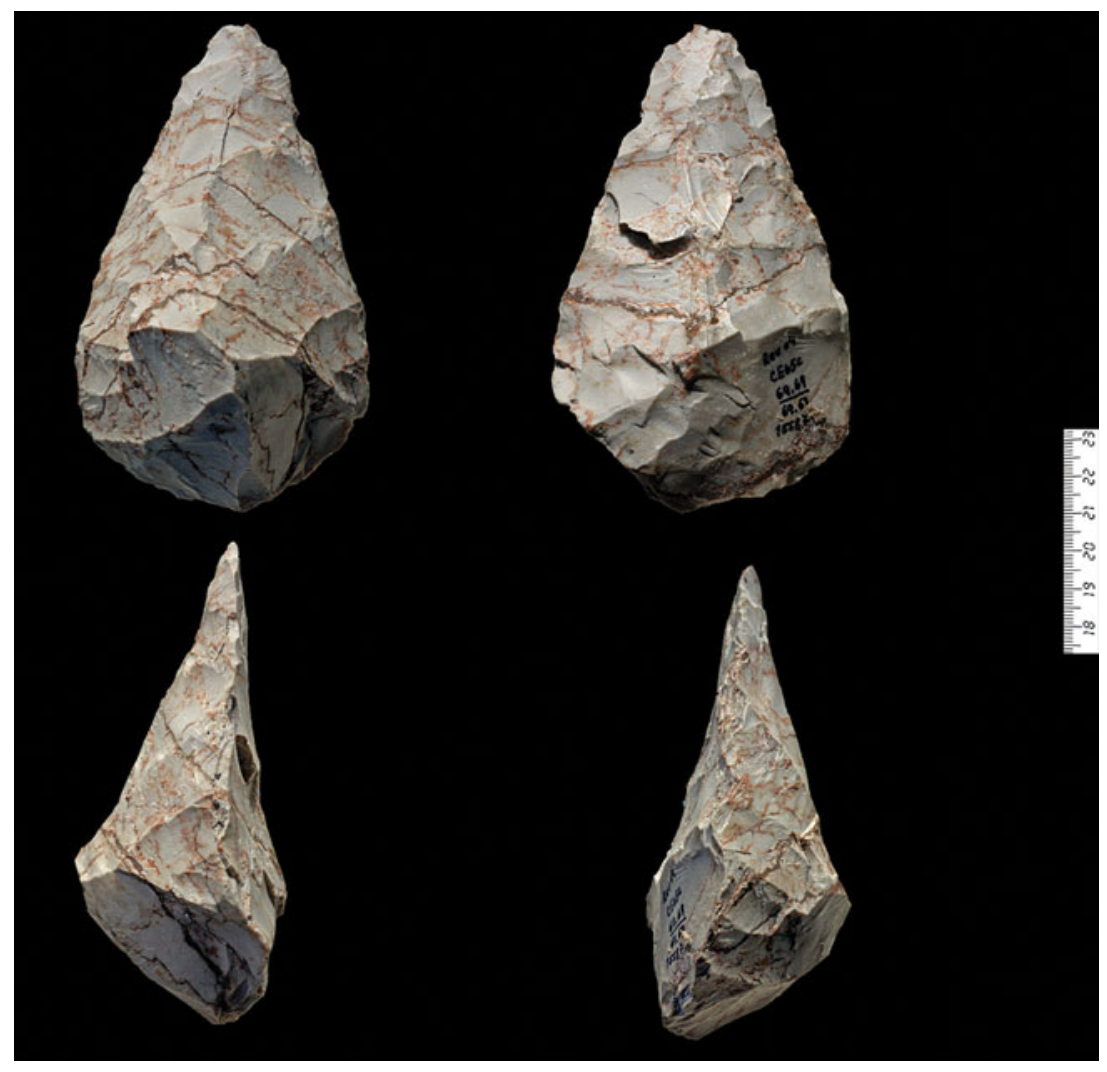

Figure 2. A replica of a flint handaxe used in experimentation of deer butchery. (Courtesy of Ruth Blasco and Jordi Rosell.)

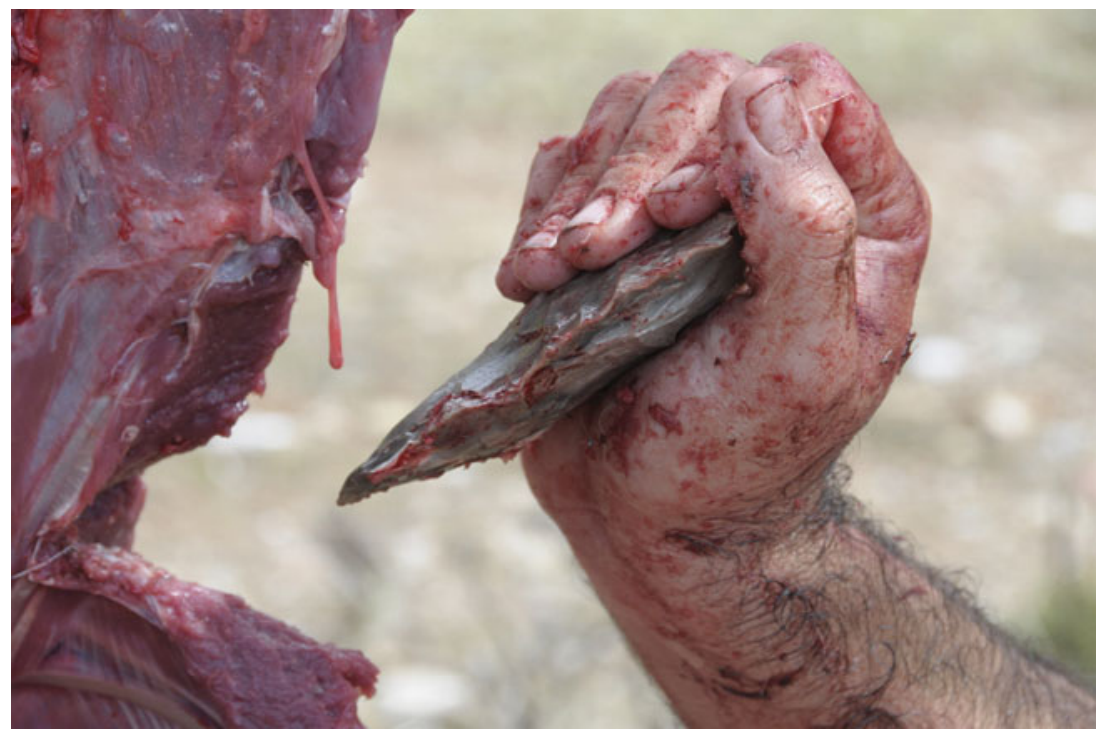

circumstances, the Ojibwa recognize, a priori, potentialities for animation in certain classes of objects under certain circumstances... The Ojibwa do not perceive stones, in general, as animate, any more than we do. The crucial test is experience. Is there any personal testimony available? In answer to this question we can say that it is asserted by informants that stones have been seen to move, that some stones manifest other animate properties, and, as we shall see, Flint is represented as a living personage in their mythology. (Hallowell 1960, 24)

More elaborate arguments appear in a wonderful, recently published book describing the lives of stone tools in Gamo hide workers ontology in Ethiopia (Arthur 2018). In the same spirit, a study 
of the Nayaka hunter-gatherers of southern India reveals their intimate familiarity with each and every elephant sharing the forest with them, while foreign elephants are treated differently and are not expected to demonstrate the norms of appropriate behaviour the Nayaka generally share with the elephants they know so well (Bird-David \& Naveh 2008). Thus, I would suggest that the co-occurrence of handaxes and elephants at the same sites, sometimes together with handaxes made of butchered elephant bones, might reflect intimate and purposeful interactions with specific elephants, while other elephants might have been treated differently (in light of such a perspective, see a similar suggestion regarding treating specific individual horses in the Upper Palaeolithic Magdalenian: Birouste 2020).

As handaxes were also used in tasks other than carcass processing, I suggest that Lower Palaeolithic hominins were much less rigid and more practical than presumed. Thus, they manipulated objects in varied ways and contexts, according to changing relationships and interactions. This perspective contradicts neither the general pattern or effectiveness of handaxes in processing large game nor the chronological and geographical association between proboscideans and bifaces. The production and use of bifaces persisted as long as elephants and mammoths were around (Ben-Dor et al. 2011; Potts et al. 2018), while after their disappearance, new stone tool technologies and modes of adaptation were introduced (Barkai et al. 2017; Blasco et al. 2019a,b; Venditti et al. 2019b).

Early humans not only consumed elephant fat and meat but also broke up elephant bones and extracted bone marrow, particularly from limb bones (Boschian et al. 2019). Acheulean early humans sometimes also used elephant bones beyond their immediate nutritional benefit, in manufacturing artefacts that closely resemble the iconic Acheulean stone handaxe (Zutovski \& Barkai 2016). Although Lower Palaeolithic Acheulean bone handaxes appear across a wide geographical range, they are a small-scale phenomenon. Bone bifaces were manufactured very similarly to the iconic stone handaxe and following shared elements of design and dexterity (Costa 2010).

Acheulean bone bifaces were mostly produced from elephant bones (Figs 3-4). All eight archaeological sites analysed (Zutovski \& Barkai 2016) contained many skeletal elements of other large herbivores, on top of the proboscidean bones available at those sites. Nonetheless, only a single handaxe was shaped from the bones of other taxa than elephants. Moreover, bone handaxes were found only at sites also containing handaxes made of stone (Zutovski \& Barkai 2016). The striking similarity between handaxes made of the butchered elephant bones and the stone handaxes that were most probably used in the butchery of these elephants is striking. We have suggested the use of the butchered elephant bones for shaping replicas of the stone handaxes served as an expression of early Acheulean humans' sense of dissonance at consuming these majestic animals with which they shared the world, and perhaps also an ontological act of ensuring the continuation of this Acheulean mode of existence. I will further argue that butchered elephant bones were purposely selected to allow early humans to 'become elephants' and to maintain the special relationship between the species, much in accordance with the arguments presented in Tanner (2014) and similarly to the way indigenous groups practised - or practise- their ontology about the animals they depend upon. It is of note that Sano et al. (2020) provide the first unequivocal evidence for the use of a 1.4 million-year-old bone handaxe from Konso in carcass processing. I suggest that this important discovery further supports a dual functional and perceptual role for these items: use of a biface does not negate a complementary role in signifying the relationships of early humans with the megafauna who sustained them and with the cosmos in general. Moreover, the occasional use of an exceptional handaxe produced from megafauna bone does not preclude any symbolic meaning. The same holds, by the way, for the stone handaxes. Given the abundance of suitable stones at Konso, the decision to transform a bone flake into a handaxe, despite stone's better workability and efficiency in butchery, testifies to an exceptional, conscious act-an act of reverence that sheds light not only on the technological sophistication of the Acheuleans, but also on their perception of the world.

\section{Ontological and cosmological theories of the world among indigenous hunter-gatherers}

Anthropological and archaeological thinking regarding the relations between indigenous groups and the world in which they live suggests that past and present hunter-gatherers were not simply exploiting natural resources. These societies view the world as composed of other-than-human persons potentially capable of thinking, feeling and decision-making. In this unique and complex view, multiple worlds might exist in parallel: a world of humans, a world of animals, a world of stone, a world of mountains, a world of rivers, and so on. The human world is just one of many, and humans are expected to live 
Figure 3. An elephant bone handaxe from Fontana Ranuccio, Italy. (Courtesy of Margherita Mussi.)
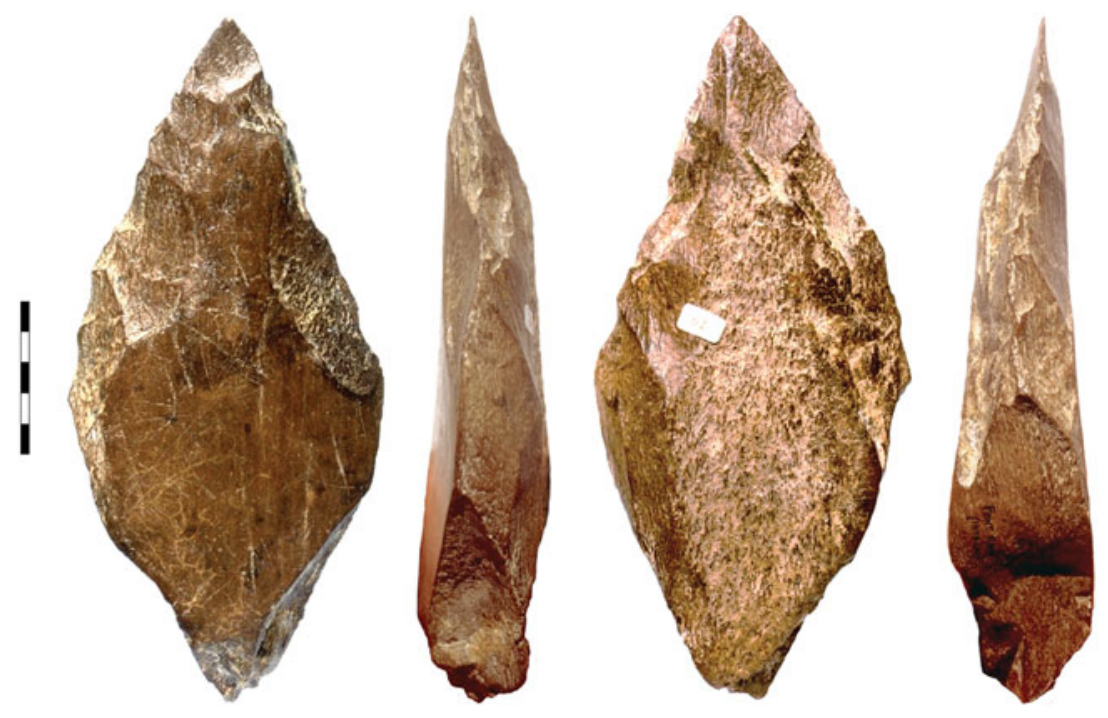

Figure 4. Elephant bone handaxe from Castel di Guido, Italy. (Courtesy of Giovanni Boschian.)

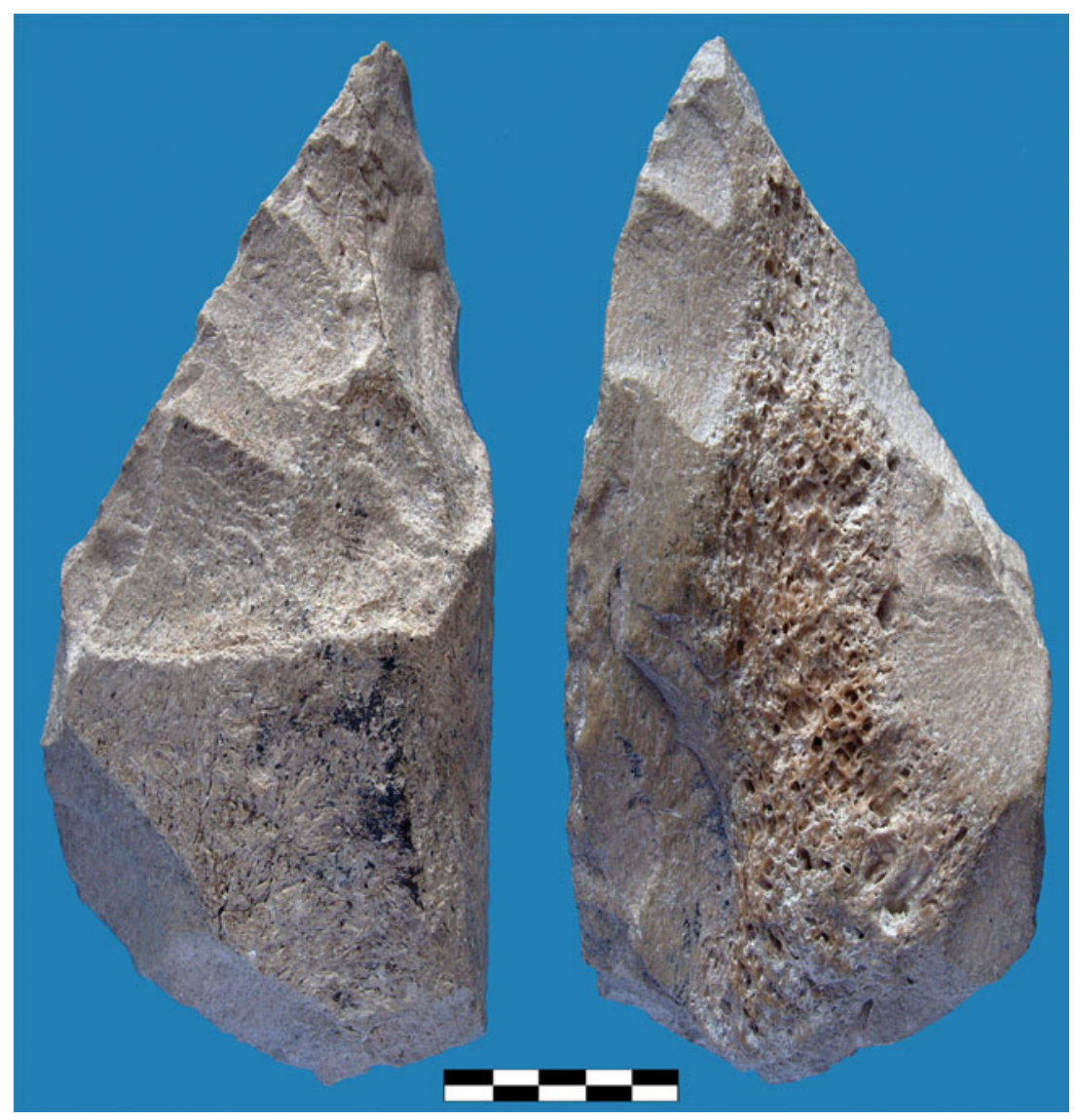

side-by-side with the other entities, maintain good relations with them and pay them respect in order to ensure world order and well-being (e.g. Alberti 2016; Betts et al. 2015; Boyd 2017; Hill 2011; 2013; A. Jones 2017; Kohn 2015; Loring 1996; Nadasdy 2007; Tanner 2014; Viveiros de Castro 1998).
This worldview had an important expression in the seeming duality of humans perceiving animals both as other-than-human persons and equal co-habitants of a shared habitat while also hunting and consuming these animal-persons (Barkai 2019; Nadasdy 2007; Tanner 2014; Willerslev 2013). The 
debate regarding human universals (Antweiler 2016; Brown 1991; 2004) is beyond the scope of this paper. While scholars highlight the diversity in huntergatherers' lifeways which is caused mostly by specific ecological adaptations (e.g. Fisher 2020; Hitchcock 2019) and/or contact with what Henrich et al. (2010) call WEIRD societies, it can be argued that certain commonalities do characterize the indigenous mode of existence, or what Barnard (2002) had termed 'The foraging mode of thought'. These might include core-values such as sharing, selfprovisioning, personal autonomy, egalitarianism and animistic ontology which are expressed by behavioural phenomena such as singing, dancing, fire-side storytelling, communicating with the cosmos via altered states of conciseness, craving for meat and fat and close encounters with animals and plants (e.g. Dyble et al. 2016; Lavi \& Friesem 2019; Lee 2006). In my view, these communalities are shared to some extent by past and present hunting societies, and specifically their reciprocal relationship with the game animals they are dependent upon. Such relationships are reflected in activities both mundane and sacred.

A recurrent idea in many recent indigenous societies is that prey animals willingly make themselves available to humans only if the hunters demonstrate appropriate behaviour towards them. In return, humans are obliged to treat the hunted animal with respect, waste nothing of the carcass, and follow strict customs regarding the use and disposal of the inedible remains:

A central attribute in the conduct of hunting is that game animals are persons and that they must be respected. The rules of respect after the killing involve essentially taking care of all elements of the carcass, and not allowing anything to be thoughtlessly discarded. Thus blood and intestines are consumed, buried in the snow, or fed to the dogs; bones are made into tools, hung in the trees, put on bone platforms, or put in a lake, and all uneaten meat is fed to the dogs or put in the fire. (Tanner 2014, 202)

And Tanner goes even further:

The more commonly held belief is that the inedible remains continue to be part of the species as a whole, and their proper treatment is a way of avoiding giving offence to the master of the species in question, thus enabling hunting to continue. (Tanner 2014, 261)

I suggest that these traits of the ontological relationships between hunters and their prey should be sought in prehistoric archaeological assemblages of all chronologies and might be reflected in the extensive exploitation of animal carcasses at archaeological sites (e.g. Barkai et al. 2017; Blasco et al. 2019a,b), in the shaping of selected inedible animal parts into tools (Barkai 2019; Blasco et al. 2013; Zutovski \& Barkai 2016), the use of inedible animal body parts in certain activities (Conneller 2004) and the insertion of animal bones in rock cracks at decorated caves (Clottes 2009; Garate et al. 2019). I would not expect this to be the case at every archaeological site where humans interacted with animals, and much of the evidence of such an ontological stance might have not been preserved. However, I am confident that the body of evidence will grow if archaeologists will be more open to the possibility of unearthing it. Then, common terms such as 'ritual', 'symbolism', 'ceremony', 'deposits', 'art' and 'ornaments' might be better understood within this ontological framework, as part of the complex human-animal relationships. The anthropocentric worldview so characteristic of WEIRD societies would best be discarded and replaced with a more cosmos-centric approach that better lends itself to reconstructing past human engagements with the world (in the spirit of the work of Lucero 2018).

\section{To please the elephant: concluding remarks}

The relationships between hunters and the animals they share the world with (but also hunt, kill and consume) are often reflected by hunters identifying themselves with the hunted animal, being 'transformed' into an animal during the hunt and often adopting the hunted animal's perspective and even sharing its feelings and emotions (e.g. Guenther 2015; Lewis-Williams \& Biesele 1978; Russell 2017). Hunters commonly make use of all parts of the prey, after the edible parts have been consumed, in order to manufacture items such as hunting gear, pendants, clothing and footwear, and amulets. They even sometimes conceal selected animal body parts on their body during the hunt (e.g. Betts et al. 2012; McNiven \& Feldman 2003; Russell 2017; Živaljević 2015). This behaviour is not only an outcome of practical necessity but is also a token of appreciation towards the animals and a mechanism aimed at both showing respect and perpetuating the significant relationships people had with these animals.

The 'nothing is wasted' concept is another facet of hunter-hunted relationships aimed at pleasing the animals (Burnham 1992; Loring 1996). The selection and use of an animal body parts is far from accidental and not directed solely by practical or technical 
considerations. As many have argued, it is an expression of the hunters' obligation to respect their prey (e.g. Tanner 2014). The intimate physical contact between the hunters and the item made from the hunted animal allows the former access to the animal's perspective and to 'transform' into the animal during the hunt and during carcass processing and consumption. They are thus granted the skills and strength of the respective animal, effectively enabling the hunters to 'become' their prey. This perspective was beautifully demonstrated in a reconstruction of the role of deer 'masks' in Mesolithic Britain: the masks were suggested not to comprise 'practical' elements used in the hunt or 'symbolic' elements with no clear explanation, but rather to consist of purposefully selected deer body-parts that enabled the hunters to transform into a deer (Conneller 2004).

In this paper I have argued that early humans shared the world with large herbivores, depended on fat and meat for their successful adaptation and well-being, and had special relationships with the animals they depended upon. Elephants are a salient example, as some proboscideans were viewed at the same time as other-than-human persons and an essential and significant source of calories. But this special relationship extended to all other prey animals as well, each taxon with its own special qualities and the specific tool-kit oriented towards its processing and appreciation.

Humans were repeatedly preoccupied by the procurement, exploitation and appreciation of elephants and other large herbivores. Thus, hunting and carcass processing were central practices in human life, well embedded in both practical and ontological adaptation strategies. I therefore suggest that specific technologies were associated with specific animal taxa, or a combination thereof, first for practical and then also for perceptual reasons, and that these relationships lasted as long as these animal taxa existed and supported human adaptation. I further argue that the dependency of human groups on specific animal taxa was a driving force behind the development of appropriate and specific technologies and tool-kits oriented towards both successful hunting and processing as well as respecting and maintaining good relationships with these animals. In this regard, the changing representations of animal taxa, and more specifically the decline in availability of large animals throughout the Pleistocene, led human groups to change their tool-kits accordingly in order to fit the practical and ontological necessities of consuming and appreciating different animal taxa. This approach might explain technological changes such as the replacement of handaxes by Levallois, to be replaced later by systematic blade production, once viewed through the lenses of the changes in animal taxa available to humans (as proboscideans were replaced by horses and cattle, which were later replaced by deer, and so on) and the possible relationships humans maintained with the specific animal taxa they were dependent upon. These factors might have led to the anchoring of specific technological adaptations as mediators, both practical and perceptual, between humans and pivotal animal taxa, as in our case of the elephant in the handaxe.

Ran Barkai

Department of Archaeology and Near Eastern Cultures Tel-Aviv University Ramat Aviv 6997801 Tel-Aviv Israel

Email:barkaran@tauex.tau.ac.il; barkaran205@gmail.com

\section{References}

Agam, A. \& R. Barkai, 2016. Not the brain alone: the nutritional potential of elephant heads in Paleolithic sites. Quaternary International 406, 218-26.

Agam, A. \& R. Barkai, 2018. Elephant and mammoth hunting during the Paleolithic: a review of the relevant archaeological, ethnographic and ethno-historical records. Quaternary 1(1), 3.

Agam, A., O. Marder \& R. Barkai, 2015. Small flake production and lithic recycling at Late Acheulean Revadim, Israel. Quaternary International 361, 46-60.

Alberti, B., 2016. Archaeologies of ontology. Annual Review of Anthropology 45, 163-79.

Aiello, L.C. \& P. Wheeler, 1995. The expensive-tissue hypothesis: the brain and the digestive system in human and primate evolution. Current Anthropology 36(2), 199-221.

Antweiler, C., 2016. Our Common Denominator: Human universals revisited. Oxford/New York: Berghahn.

Arthur, K.W. 2018. The Lives of Stone Tools: Crafting the status, skill, and identity of flintknappers. Tucson (AZ): University of Arizona Press.

Aureli, D., A. Contardi, B. Giaccio, et al., 2015. Palaeoloxodon and human interaction: depositional setting, chronology and archaeology at the Middle Pleistocene Ficoncella site (Tarquinia, Italy). PLoS One 10(4), e0124498.

Barkai, R., 2019. An elephant to share: rethinking the origins of meat and fat sharing in Paleolithic societies, in Towards a Broader View of Hunter Gatherer Sharing, eds N. Lavi \& D.E. Friesem. Cambridge: McDonald Institute for Archaeological Research, 153-67. 
Barkai, R., J. Rosell, R. Blasco \& A. Gopher, 2017. Fire for a reason: barbecue at middle Pleistocene Qesem cave, Israel. Current Anthropology 58(S16), S314-S328.

Barnard, A., 2002. The foraging mode of thought. Senri Ethnological Studies 60, 5-24.

Ben-Dor, M. \& R. Barkai, 2020. The importance of large prey animals during the Pleistocene and the implications of their extinction on the use of dietary ethnographic analogies. Journal of Anthropological Archaeology 59, 101192.

Ben-Dor, M. \& R. Barkai, in press. Supersize does matter: the importance of large prey in Paleolithic subsistence and a method for measurement of its significance, in zooarchaeological assemblages, in Human-Elephant Interactions: From past to present, eds G. Konidaris, R. Barkai, V. Tourloukis \& K. Harvati. Tübingen: Tübingen University Press.

Ben-Dor, M., A. Gopher, I. Hershkovitz \& R. Barkai, 2011. Man the fat hunter: the demise of Homo erectus and the emergence of a new hominin lineage in the Middle Pleistocene (ca. 400 kyr) Levant. PLoS One 6 (12): e28689.

Ben-Dor, M., A. Gopher \& R. Barkai, 2016. Neandertals' large lower thorax may represent adaptation to high protein diet. American Journal of Physical Anthropology 160(3), 367-78.

Betts, M.W., S.E. Blair \& D.W. Black, 2012. Perspectivism, mortuary symbolism, and human-shark relationships on the Maritime Peninsula. American Antiquity 77(4), 621-45.

Betts, M.W., M. Hardenberg \& I. Stirling, 2015. How animals create human history: relational ecology and the Dorset-polar bear connection. American Antiquity 80(1), 89-112.

Biesele, M., 1993. Women Like Meat: The folklore and foraging ideology of the Kalahari Ju/'Hoan. Johannesburg: Witwatersrand University Press.

Bird-David, N. \& D. Naveh, 2008. Relational epistemology, immediacy, and conservation: or, what do the Nayaka try to conserve? Journal for the Study of Religion, Nature and Culture 2(1), 55-73.

Birouste, C., 2020. Human and animal individuals in the Middle Magdalenian. Journal of Archaeological Method and Theory 27, 607-30.

Blasco, R., J. Rosell, M. Arilla, A. Margalida, D. Villalba, A. Gopher \& R. Barkai, 2019b. Bone marrow storage and delayed consumption at Middle Pleistocene Qesem Cave, Israel (420 to $200 \mathrm{ka}$ ). Science Advances 5(10), eaav9822.

Blasco, R., J. Rosell, F. Cuartero, J.F. Peris, A. Gopher \& R. Barkai, 2013. Using bones to shape stones: MIS 9 bone retouchers at both edges of the Mediterranean Sea. PLoS One 8(10), e76780.

Blasco, R., J. Rosell, A. Sánchez-Marco, A. Gopher \& R. Barkai, 2019a. Feathers and food: human-bird interactions at Middle Pleistocene Qesem Cave, Israel. Journal of Human Evolution 136, 102653.
Bocherens, H., 2009. Neanderthal dietary habits: review of the isotopic evidence, in Evolution of Hominin Diets, eds J.J. Hublin \& M.P. Richards. Heidelberg: Springer, 241-50.

Bocherens, H., 2011. Diet and ecology of Neanderthals: implications from $\mathrm{C}$ and $\mathrm{N}$ isotopes, in Neanderthal Lifeways: Subsistence and technology, eds N.J. Conard \& J. Richter. Tübingen: Springer, 73-85.

Bocherens, H., in press. Isotopic insights on the ecological interactions between humans and woolly mammoths during the Middle and Upper Palaeolithic in Europe, in Human-Elephant Interactions: From past to present, eds G. Konidaris, R. Barkai, V. Tourloukis \& K. Harvati. Tübingen: Tübingen University Press.

Boschian, G., D. Caramella, D. Saccà \& R. Barkai, 2019. Are there marrow cavities in Pleistocene elephant limb bones, and was marrow available to early humans? New CT scan results from the site of Castel di Guido (Italy). Quaternary Science Reviews 215, 86-97.

Boyd, B., 2017. Archaeology and human-animal relations: thinking through anthropocentrism. Annual Review of Anthropology 46, 299-316.

Braun, I.M. \& M.R. Palombo, 2012. Mammuthus primigenius in the cave and portable art: an overview with a short account on the elephant fossil record in Southern Europe during the last glacial. Quaternary International 276, 61-76.

Brown, D.E., 1991. Human Universals. New York (NY): McGraw Hill.

Brown, D. E., 2004. Human universals, human nature \& human culture. Daedalus 133(4), 47-54.

Bunn, H.T., 2006. Meat made us human, in Evolution of the Human Diet: The known, the unknown, and the unknowable, ed. P. Ungar. Oxford: Oxford University Press, 191-211.

Bunn, H.T., 2019. Large ungulate mortality profiles and ambush hunting by Acheulean-age hominins at Elandsfontein, Western Cape Province, South Africa. Journal of Archaeological Science 107, 40-49.

Burnham, D.K., 1992. To Please the Caribou: Painted caribouskin coats worn by the Naskapi, Montagnais, and Cree hunters of the Quebec-Labrador Peninsula. Seattle (WA): University of Washington Press.

Churchill, S.E., 1993. Weapon technology, prey size selection, and hunting methods in modern huntergatherers: implications for hunting in the Palaeolithic and Mesolithic. Archeological Papers of the American Anthropological Association 4(1), 11-24.

Clottes, J., 2009. Sticking bones into cracks in the Upper Palaeolithic, in Becoming Human: Innovation in prehistoric material and spiritual culture, eds C. Renfrew \& I. Morley. Cambridge: Cambridge University Press, 195-211.

Conneller, C., 2004. Becoming deer. Corporeal transformations at Star Carr. Archaeological Dialogues 11(1), 37-56.

Costa, A.G., 2010. A geometric morphometric assessment of plan shape in bone and stone Acheulean bifaces 
from the Middle Pleistocene site of Castel di Guido, Latium, Italy, in New Perspectives on Old Stones, eds S.J. Lycett \& P.R. Chauhan. New York (NY): Springer, 23-41.

Domínguez-Rodrigo, M. \& T.R. Pickering, 2017. The meat of the matter: an evolutionary perspective on human carnivory. Azania: Archaeological Research in Africa 52(1), 4-32.

Domínguez-Rodrigo, M., J. Serrallonga, J. Juan-Tresserras, L. Alcala \& L. Luque, 2001. Woodworking activities by early humans: a plant residue analysis on Acheulian stone tools from Peninj (Tanzania). Journal of Human Evolution 40, 289-99.

Dyble, M., J. Thompson, D. Smith, et al., 2016. Networks of food sharing reveal the functional significance of multilevel sociality in two hunter-gatherer groups. Current Biology 26(15), 2017-21.

Faith, J.T., J. Rowan, A. Du \& P.L. Koch, 2018. Plio-Pleistocene decline of African megaherbivores: no evidence for ancient hominin impacts. Science 362(6417), 938-41.

Finkel, M. \& R. Barkai, 2018. The Acheulean handaxe technological persistence - lack of innovation or a case of preferred conservatism? Proceedings of the Prehistoric Society 84, 1-19.

Fisher, J.L., 2020. Diversity of forager lifeways in the prehistoric past. Antiquity 94, 533-35.

Friedman, M., 1996. Nutritional value of proteins from different food sources. A review. Journal of Agricultural Food Chemistry 44, 6-29.

Gallotti, R. \& C. Peretto, 2015. The Lower/early Middle Pleistocene small débitage productions in western Europe: new data from Isernia La Pineta t. 3c (Upper Volturno Basin, Italy). Quaternary International 357, 264-81.

Garate, D., A. Labarge, O. Rivero, I. Intxaurbe, C. Barshay-Szmidt \& C. Normand, 2019. Another bone in the wall: towards a characterisation of the objects placed in wall fissures at Isturitz cave (Pyrénées-Atlantiques, France). Archaeological and Anthropological Sciences 11(12), 6875-87.

Gaudzinski, S., E. Turner, A.P. Anzidei, et al., 2005. The use of Proboscidean remains in every-day Palaeolithic life. Quaternary International 126, 179-94.

Givens, D.I., K.E. Kliem \& R.A. Gibbs, 2006. The role of meat as a source of $n-3$ polyunsaturated fatty acids in the human diet. Meat Science 74(1), 209-18.

Goren-Inbar, N., N., Alperson-Afil, G. Sharon \& G. Herzlinger, 2018. The Acheulian Site of Gesher Benot Ya'aqov Volume IV: The Lithic Assemblages. Heidelberg: Springer.

Guenther, M., 2015. 'Therefore their parts resemble humans, for they feel that they are people'. Ontological flux in San myth, cosmology and belief. Hunter Gatherer Research 1(3), 277-315.

Guil-Guerrero J.L., A. Tikhonov, I. Rodríguez-García, A. Protopopov, S. Grigoriev \& R.P. Ramos-Bueno, 2014. The fat from frozen mammals reveals sources of essential fatty acids suitable for Palaeolithic and Neolithic humans. PLoS One 9(1), e84480.

Guil-Guerrero J.L., A. Tikhonov, R.P. Ramos-Bueno, S. Grigoriev, A. Protopopov, G. Savvinov \& M.J. González-Fernández, 2018. Mammoth resources for hominins: from omega-3 fatty acids to cultural objects. Journal of Quaternary Science 33(4), 455-63.

Hallowell, A.I., 1960. Ojibwa ontology behavior, and world view, in Culture in History: Essays in honor of Paul Radin, ed. S. Diamond. New York (NY): Columbia University Press, 19-52.

Hardy, K., J. Brand-Miller, K.D. Brown, M.G. Thomas \& L. Copeland, 2015. The importance of dietary carbohydrate in human evolution. Quarterly Review of Biology 90(3), 251-68.

Hardy, B.L., M.H. Moncel, J. Despriée, G. Courcimault \& P. Voinchet, 2018. Middle Pleistocene hominin behavior at the 700ka Acheulean site of la Noira (France). Quaternary Science Reviews 199, 60-82.

Henrich, J., S.J., Heine \& A. Norenzayan, 2010. The weirdest people in the world? Behavioral and Brain Sciences 33(2-3), 61-83.

Hill, E., 2011. Animals as agents: hunting ritual and relational ontologies in prehistoric Alaska and Chukotka. Cambridge Archaeological Journal 21(3), 407-26.

Hill, E., 2013. Archaeology and animal persons: toward a prehistory of human-animal relations. Environment and Society: Advances in Research 4, 117-36.

Hitchcock, R.K., 2019. Hunters and gatherers past and present: perspectives on diversity, teaching, and information transmission. Reviews in Anthropology 48(1), 5-37.

Hussain, S.T. \& H. Floss, 2015. Sharing the world with mammoths, cave lions and other beings: linking animal-human interactions and the Aurignacian 'belief world'. Quartär 62, 85-120.

Jones, P.R., 1980. Experimental butchery with modern stone tools and its relevance for Palaeolithic archaeology. World Archaeology 12, 153-65.

Jones, P.R., 1981. Experimental implement manufacture and use; a case study from Olduvai Gorge, Tanzania. Philosophical Transactions of the Royal Society of London B: Biological Sciences 292(1057), 189-95.

Jones, A.M., 2017. Rock art and ontology. Annual Review of Anthropology 46, 167-81.

Keeley, L.H., 1980. Experimental Determination of Stone Tool Uses: A microwear analysis. Chicago (IL): University of Chicago Press.

Key, A.J.M. \& S.J. Lycett, 2015. Edge angle as a variably influential factor in flake cutting efficiency: an experimental investigation of its relationship with tool size and loading. Archaeometry 57, 911-27.

Key, A.J.M. \& S.J. Lycett, 2017. Influence of handaxe size and shape on cutting efficiency: a large-scale experiment and morphometric analysis. Journal of Archaeological Method and Theory 24(2), 514-41. 
Kimmerer, R.W., 2018. Mishkos Kenomagwen, the lessons of grass: restoring reciprocity with the good green earth, in Traditional Ecological Knowledge: Learning from indigenous practices for environmental sustainability, eds M. Nelson \& D. Shilling. Cambridge: Cambridge University Press, 27-56.

Kohn, E., 2015. Anthropology of ontologies. Annual Review of Anthropology 44, 311-32.

Lavi, N. \& D.E. Friesem (eds), 2019. Towards a Broader View of Hunter Gatherer Sharing. Cambridge: McDonald Institute for Archaeological Research.

Lee, R.B., 2006. Commonalities and diversities in contemporary hunter-gatherers: from settlement archaeology to development ethnography. Archeological Papers of the American Anthropological Association 16 (1), 157-69.

Lev, M. \& R. Barkai, 2016. Elephants are people, people are elephants: elephant food taboos as a case for crosscultural animal humanization in recent and Paleolithic times. Quaternary International 406(2), 239-45.

Lewis, J.D., 2015. Where goods are free but knowledge costs: hunter-gatherer ritual economics in Western Central Africa. Hunter-Gatherer Research 1(1), 1-27.

Lewis-Williams, J.D. \& M. Biesele, 1978. Eland hunting rituals among northern and southern San groups: striking similarities. Africa 48(2), 117-34.

Loring, S., 1996. To please the animal master: the Innu hunting way of life. Tribal College 7(4), 20-23.

Lucero, L.J., 2018. A cosmology of conservation in the ancient Maya world. Journal of Anthropological Research 74(3), 327-59.

Lycett, S.J. \& J.A.J. Gowlett, 2008. On questions surrounding the Acheulean 'tradition'. World Archaeology 403, 295-315.

Machin, A., J. Robert, T. Hosfield \& S. Mithen, 2007. Why are some handaxes symmetrical? Testing the influence of handaxe morphology on butchery effectiveness. Journal of Archaeological Science 34(6), 883-93.

McNiven, I.J. \& R. Feldman, 2003. Ritually orchestrated seascapes: hunting magic and dugong bone mounds in Torres Strait, NE Australia. Cambridge Archaeological Journal 13(2), 169-94.

Mitchell, J.C., 1996. Studying biface utilisation at Boxgrove: roe deer butchery with replica handaxes. Lithics 16, 64-9.

Morin, E., 2020. Rethinking the emergence of bone grease procurement. Journal of Anthropological Archaeology $59,101178$.

Nadasdy, P., 2007. The gift in the animal: the ontology of hunting and human-animal sociality. American Ethnologist 34(1), 25-43.

Outram, A., 2002. Bone fracture and within-bone nutrients: an experimentally based method for investigating levels of marrow extraction, in Consuming Passions and Patterns of Consumption, eds P. Miracle \& N. Milner. Cambridge: McDonald Institute for Archeological Research, 51-63.
Pobiner, B.L., M.J. Rogers, C.M. Monahan \& J.W. Harris, 2008. New evidence for hominin carcass processing strategies at $1.5 \mathrm{Ma}$, Koobi Fora, Kenya. Journal of Human Evolution 55(1), 103-30.

Pope, M. \& M. Roberts, 2005. Observations on the relationship between Palaeolithic individuals and artefact scatters at the Middle Pleistocene site of Boxgrove, $\mathrm{UK}$, in The Individual Hominid in Context: Archaeological investigations of Lower and Middle Palaeolithic landscapes, locales and artefacts, eds C. Gamble \& M. Porr. London: Routledge, 81-97.

Potts, R., A.K, Behrensmeyer, J.T. Faith, et al., 2018. Environmental dynamics during the onset of the Middle Stone Age in eastern Africa. Science 360 (6384), 86-90.

Reshef, H. \& R. Barkai, 2015. A taste of an elephant: the probable role of elephant meat in Paleolithic diet preferences. Quaternary International 379, 28-34.

Russell, T., 2017. 'People will no longer be people but will have markings and be animals': investigating connections between diet, myth, ritual and rock art in southern African archaeology. Azania: Archaeological Research in Africa 52(2), 192-208.

Sano, K., Y. Beyene, S. Katoh, et al., 2020. A 1.4-million-year-old bone handaxe from Konso, Ethiopia, shows advanced tool technology in the early Acheulean. Proceedings of the National Academy of Sciences of the USA 117, 18393-400.

Smith F.A., R.E.E. Smith, S.K. Lyons \& J.L. Payne, 2018. Body size downgrading of mammals over the late Quaternary. Science 360(6386), 310-13.

Solodenko, N., A. Zupancich, S.N. Cesaro, O. Marder, C. Lemorini \& R. Barkai, 2015. Fat residue and usewear found on Acheulian biface and scraper associated with butchered elephant remains at the site of Revadim, Israel. PloS One 10(3), e0118572.

Speth, J.D., 2020. Paleoindian bison hunting on the North American Great Plains - two critical nutritional constraints. PaleoAnthropology 74, 97.

Tanner, A., 2014. Bringing Home Animals: Mistissini hunters of Northern Quebec. St Johns: ISER Books.

Van Kolfschoten, T., E. Buhrs \& I. Verheijen, 2015. The larger mammal fauna from the Lower Paleolithic Schöningen Spear site and its contribution to hominin subsistence. Journal of Human Evolution 89, 138-53.

Venditti, F., E. Cristiani, S. Nunziante-Cesaro, A. Agam, C. Lemorini \& R. Barkai, 2019a. Animal residues found on tiny Lower Paleolithic tools reveal their use in butchery. Scientific Reports 9(1), 1-14.

Venditti, F., S.N., Cesaro, Y. Parush, A. Gopher \& R. Barkai, 2019b. Recycling for a purpose in the late Lower Paleolithic Levant: use-wear and residue analyses of small sharp flint items indicate a planned and integrated subsistence behavior at Qesem Cave (Israel). Journal of Human Evolution 131, 109-28.

Viveiros de Castro, E., 1998. Cosmological deixis and Amerindian perspectivism. Journal of the Royal Anthropological Institute 4(3), 469-88. 
Werdelin, L. \& M.E. Lewis, 2013. Temporal change in functional richness and evenness in the eastern African Plio-Pleistocene carnivoran guild. PLoS One 8(3), e57944.

Willerslev, R., 2013. Taking animism seriously, but perhaps not too seriously? Religion and Society 4(1), 41-57.

Zink, K.D. \& D.E. Lieberman, 2016. Impact of meat and Lower Palaeolithic food processing techniques on chewing in humans. Nature 531, 500-503.

Živaljević, I., 2015. Concepts of the body and personhood in the Mesolithic-Neolithic Danube gorges: interpreting animal remains from human burials. Issues in Ethnology and Anthropology 10, 675-99.

Zupancich, A., N. Solodenko, T. Rosenberg-Yefet \& R. Barkai, 2018. On the function of Late Acheulean stone tools: new data from three specific archaeological contexts at the Lower Palaeolithic site of Revadim, Israel. Lithic Technology 43, 255-68.

Zutovski, K. \& R. Barkai, 2016. The use of elephant bones for making Acheulian handaxes: a fresh look at old bones. Quaternary International 406, 227-38.

\section{Author biography}

Ran Barkai (PhD, 2000, Tel-Aviv University) is Professor of Prehistoric Archaeology and former chair of the Department of Archaeology and Ancient Near Eastern Cultures, Tel Aviv University. Together with Professor Avi Gopher, he co-directs excavations at the Middle Pleistocene site of Qesem Cave. He has published extensively on different aspects of Palaeolithic and Neolithic technology, subsistence, cosmology and lifeways. 